\title{
High frequency wheat regeneration from leaf tissue explants of regenerated plantlets
}

\author{
Huimin $\mathrm{Yu}^{1}$, Wenchao Wang ${ }^{2}$, Yanwen Wang ${ }^{2}$, Bingkai Hou ${ }^{2 *}$ \\ ${ }^{1}$ Department of Biology, Qilu Normal University, Jinan, China \\ ${ }^{2}$ The Key Lab of Plant Cell Engineering and Germplasm Innovation, Ministry of Education of China and School of Life Science, \\ Shandong University, Jinan, China \\ Email: ${ }^{\text {bkhou@sdu.edu.cn }}$
}

Received 10 October 2011; revised 13 November 2011; accepted 15 December 2011

\begin{abstract}
The specificities of tissue culture of wheat greatly limit the use of chloroplast transformation technologies in this crop. One limitation in wheat tissue culture is that it is difficult to regenerate plantlets from leaf tissue explants of regenerated plantlets, resulting in difficulty in obtaining homoplastic plants via multiple rounds of antibiotic selection of chloroplast transformants. Thus, a repeated in vitro regeneration system from leaf tissues was studied in this research. Our results showed that $2 \mathrm{~mm}$ leaf basal segments of the $4 \mathrm{~cm}$ high leaves from regenerated plantlets can give the best callus induction at present study. The best callus induction medium was Murashige and Skoog (MS) basal medium supplemented with $2 \mathrm{mg} / \mathrm{L}$ 2,4-dichlorophenoxyacetic acid and $1 \mathrm{mg} / \mathrm{L}$ naphthalenacetic acid, which gave a callus induction rate of up to $87.2 \%$. The optimal differentiation medium was MS basal medium supplemented with $10 \mathrm{mg} / \mathrm{L}$ silver nitrate and $1 \mathrm{mg} / \mathrm{L}$ 2,3,5-triiodobenzoic acid, which gave a regeneration rate up to $33.7 \%$ for the wheat lines tested. This is the first report showing that leaf basal segments of in vitro regenerated plantlets can be used for regeneration of wheat. The establishment of a repetitive regeneration system should pave the way for the development of chloroplast transformation and the plant regeneration systems starting from leaf material of in vitro regenerated wheat and other cereal crops.
\end{abstract}

Keywords: Wheat (Triticum aestivum L.); In Vitro Repetitive Regeneration; Leaf Segment; Tissue Culture; Chloroplast Transformation

\section{INTRODUCTION}

For wheat (Triticum aestivum) and other cereal crops,

"Corresponding author. regenerated plants from tissue culture have mainly been from calli derived from immature embryos or inflorescences. It has also been reported that wheat plants were regenerated from leaf basal segments of seedlings germinated for 3 - 5 days [1,2]. Leaf basal segments of seedling have frequently consisted of mixed tissues including leaf tissue and other tissues, usually coleoptile tissue [1]. Therefore, it is not clear whether the regenerated plants were only from leaf tissues or not. Leaf explants of in vitro regenerated wheat plantlets are pure and unmixed green leaf tissues; however, no report has yet described the regeneration of wheat plantlets from this type of leaf tissue. Therefore, green leaf tissues of wheat have not yet been used as explants in current chloroplast transformation. As a result, homoplastic tissues cannot be produced via multiple rounds of regeneration of plants using leaves as explants and thus this limits the extension of chloroplast transformation technology to monocotyledonous cereal crops. Due to the limitation mentioned above, there has been only one report of plastid transformation in a monocotyledonous plant-in rice [3].

In this study, the green leaf tissues of in vitro regenerated plantlets, not seedlings, were used as explants in wheat tissue culture and a repeatable wheat regeneration from leaf to leaf was accomplished. This method will be of importance not only for plastid transformation of graminaceous species but also for improved plant regeneration systems starting from in vitro produced leaf material.

\section{MATERIALS AND METHODS}

\subsection{Plant Materials}

Two genotypes of wheat (T. aestivum), Jinan177 (JN177) and Chinese Spring (CS), were used. JN177 is a broadly cultivated wheat cultivar in Shandong Province, China. CS is a commonly used model in wheat research worldwide. These materials were grown in an experimental field of Shandong University, China. 


\subsection{Tissue Culture Media}

Callus induction medium I: composed of Murashige and

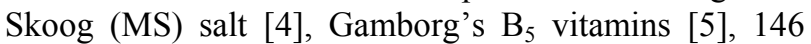
$\mathrm{mg} / \mathrm{L}$ glutamine, $200 \mathrm{mg} / \mathrm{L}$ hydrolyzed casein, $1 \mathrm{mg} / \mathrm{L}$ 2,4-dichlorophenoxyacetic acid (2,4-D), $6.5 \mathrm{~g} / \mathrm{L}$ agar (Sangon Biotech Co Ltd., Shanghai, China), and $30 \mathrm{~g} / \mathrm{L}$ sucrose at $\mathrm{pH}$ 5.7.

Callus induction medium II: composed of MS salt, $\mathrm{B}_{5}$ vitamins, $150 \mathrm{mg} / \mathrm{L}$ L-asparagine, $2 \mathrm{mg} / \mathrm{L} \mathrm{2,4-D,} 0$ - 2 $\mathrm{mg} / \mathrm{L}$ 1-naphthalenacetic acid (NAA), $6.5 \mathrm{~g} / \mathrm{L}$ agar, and $30 \mathrm{~g} / \mathrm{L}$ sucrose at $\mathrm{pH} 5.7$.

Callus subculture medium: composed of MS salt, $\mathrm{B}_{5}$ vitamins, $146 \mathrm{mg} / \mathrm{L}$ glutamine, $2 \mathrm{mg} / \mathrm{L} \mathrm{2,4-D,} 6.5 \mathrm{~g} / \mathrm{L}$ agar, and $30 \mathrm{~g} / \mathrm{L}$ sucrose at $\mathrm{pH} 5.7$.

Differentiation medium I: composed of MS salt, $\mathrm{B}_{5}$ vitamins, $146 \mathrm{mg} / \mathrm{L}$ glutamine, $1 \mathrm{mg} / \mathrm{L} N^{6}$-benzyladenine (6-BA), $0.5 \mathrm{mg} / \mathrm{L}$ indole-3-acetic acid (IAA), $6.5 \mathrm{~g} / \mathrm{L}$ agar, and $30 \mathrm{~g} / \mathrm{L}$ sucrose at $\mathrm{pH} 5.7$.

Differentiation medium II: composed of MS salt, $\mathrm{B}_{5}$ vitamins, $146 \mathrm{mg} / \mathrm{L}$ glutamine, $1 \mathrm{mg} / \mathrm{L}$ 6-BA, $0.5 \mathrm{mg} / \mathrm{L}$ IAA, 0 - $10 \mathrm{mg} / \mathrm{L}$ silver nitrate $\left(\mathrm{AgNO}_{3}\right), 0-1 \mathrm{mg} / \mathrm{L}$ 2,3,5-triiodobenzoic acid (TIBA), $6.5 \mathrm{~g} / \mathrm{L}$ agar, and 30 $\mathrm{g} / \mathrm{L}$ sucrose at $\mathrm{pH} 5.7$.

\subsection{Induction and Subculture of Embryogenic Calluses}

Immature ears of wheat were collected at $14-16 \mathrm{~d}$ post anthesis stage and surface sterilized with $300 \mathrm{~mL}$ of $75 \%$ alcohol for 3 - $8 \mathrm{~min}$. Immature embryos (0.6 - $1.2 \mathrm{~mm})$ were dissected out from the kernels using a dissecting needle and cultured on callus induction medium I. About 15 embryos were put on each plate and cultured at $25^{\circ} \mathrm{C}$ in darkness.

After 2 weeks of culture, the yellowish and compact embryogenic calli had formed and these were then subcultured on callus subculture medium at $25^{\circ} \mathrm{C}$ with a $16 / 8 \mathrm{~h} \mathrm{light/dark}$ period with a light intensity of 60 $\mu \mathrm{mol} \cdot \mathrm{m}^{-2} \cdot \mathrm{s}^{-1}$.

\subsection{Regeneration of First Generation of Wheat Plantlets}

After 3 weeks of subculture in callus subculture medium, the embryogenic calli were transferred onto the differentiation medium I and cultured at $25^{\circ} \mathrm{C}$ with a $16 / 8 \mathrm{~h}$ light/dark period. The first generation plantlets were initiated within 2 weeks.

\subsection{Repeated Regeneration of Wheat Plantlets}

Appropriate sizes of the first generation of in vitro regenerated wheat plantlets were selected and dissected from the calluses. The $2 \mathrm{~mm}$ leaf basal segments from the basal parts of the first generation plantlets were cut and transferred onto callus induction medium II for induction of embryogenic calluses in darkness. After 3 - 4 weeks of incubation, callus clumps were observed from leaf basal segments. The number of callus clumps of 2 $4 \mathrm{~mm}$ size were counted and used for statistical analysis of induction rate of the second generation callus (i.e. percentage of leaf basal segments producing callus in the total number of leaf basal segments used).

The calli were subcultured onto callus induction medium II for another three weeks. Embryogenic calli were then transferred onto differentiation medium II for regeneration of the second generation plantlets at $25^{\circ} \mathrm{C}$ with 16/8 h light/dark period. After 3 - 4 weeks of culture, the second generation plantlets were regenerated and the number of plantlets counted. The regeneration rate of the second generation plantlets was expressed as the percentage of calli producing plantlets in total number of calli used.

\subsection{Statistical Analysis}

All experiments were conducted with a minimum of 40 explants. All assays were repeated at least three times. The experimental data were statistically analyzed by one-way ANOVA using the protected least-significant difference (LSD) test $(P<0.05)$ and were presented as the average \pm standard error (SE).

\section{RESULTS}

\subsection{Effects of Different NAA Concentrations on Callus Induction from Leaf Basal Segments of the First Generation Plantlets}

For the first generation plantlets, both wheat cultivars had approximately $90 \%$ regeneration rates when their immature embryo calli were cultured on the differentiation medium I for 2 weeks (data not shown). After 3 - 4 weeks, plantlet leaves were approximately $3 \mathrm{~cm}$ long and were then used for sectioning leaf basal segments of 2 $\mathrm{mm}$ length. These leaf basal segments were cultured on callus induction medium II containing different concentrations of NAA for induction of embryogenic calli. On callus induction medium II containing $1 \mathrm{mg} / \mathrm{L}$ NAA, leaf basal segments from JN177 and CS plantlets had the highest callus induction rates of $81 \%$ and $73.7 \%$, respecttively (Figure 1). However, on callus induction medium II containing $2 \mathrm{mg} / \mathrm{L} \mathrm{NAA}$, the callus induction rates for JN177 and CS were $31.3 \%$ and $26.3 \%$, respectively; and without NAA the corresponding values were $43.7 \%$ and $49.3 \%$. The three concentrations of NAA caused signifycantly different callus induction rates. These results suggested that the growth regulator NAA was a key factor for callus induction from leaf basal tissues (Table 1). 


\subsection{Effects of Leaf Size of the First Generation Plantlets on Callus Induction}

In this experiment, leaves of different sizes $(2 \pm 0.5,4 \pm$ 0.5 and $6 \pm 0.5 \mathrm{~cm}$ ) from the first generation plantlets were chosen for sectioning $2 \mathrm{~mm}$ basal segments and to compare callus induction. After 3 weeks of culture on callus induction medium II containing $1 \mathrm{mg} / \mathrm{L}$ NAA, the leaf basal segments from leaves of $4 \pm 0.5 \mathrm{~cm}$ length gave the highest callus induction rate, reaching $87.2 \%$ and $79.4 \%$ in JN177 and CS, respectively (Table 2). Shorter $(2 \pm 0.5 \mathrm{~cm})$ or longer $(6 \pm 0.5 \mathrm{~cm})$ leaves gave lower callus induction rates, of $60.5 \%$ and $43.9 \%$ for JN177, and $60 \%$ and $40.5 \%$ for CS, respectively. In addition, callus induction rates of different parts of plantlet leaves were investigated; the upper parts of plantlet leaves had a much lower callus induction rate than from the basal part (data not shown). These results suggested that the leaf size and the position of leaf segments were crucial factors influencing callus induction.

\subsection{Effects of $\mathrm{AgNO}_{3}$ and TIBA on the Regeneration of the Second Generation Plantlets}

Differentiation medium I, which contained $1 \mathrm{mg} / \mathrm{L}$ 6-BA and $0.5 \mathrm{mg} / \mathrm{L}$ IAA, has been shown to be a very good medium for the regeneration of the first generation plantlets from immature embryo calli in our laboratory [6, 7]. However, this medium gave very low regeneration efficiency $(\approx 5 \%)$ for the second generation plantlets from leaf basal segment calli (Table 3). To increase regeneration efficiency of leaf basal segment calli, we tested the effects of different concentrations of $\mathrm{AgNO}_{3}$ and TIBA added to differentiation medium II. CS showed signifycantly increased regeneration rates when $10 \mathrm{mg} / \mathrm{L} \mathrm{AgNO}_{3}$ and/or $1 \mathrm{mg} / \mathrm{L}$ TIBA were added (Table 3). For JN177, the best regeneration rate was with differentiation medium II containing both $10 \mathrm{mg} / \mathrm{L} \mathrm{AgNO}_{3}$ and $1 \mathrm{mg} / \mathrm{L}$ TIBA - the regeneration rates of the second generation of JN177 plantlets from leaf basal segment calli were $33.7 \%$. If differentiation medium II contained only one or none of $\mathrm{AgNO}_{3}$ and TIBA, the regeneration rate of the second generation JN177 plantlets was reduced signifycantly (Table 3). These results demonstrated that both $\mathrm{AgNO}_{3}$ and TIBA had significant effects on plantlet regeneration from leaf basal segment calli of first generation plantlets.

\subsection{Establishment of in Vitro Repeated Wheat Regeneration System}

In our experiments, the optimized protocol was tested for the in vitro repeated regeneration system of wheat. The embryogenic calli from immature embryos or inflores-
Table 1. Callus induction rate of leaf basal segments. Leaf basal segments of $\approx 3 \mathrm{~cm}$ long leaves of the first generation wheat plantlets were cut and cultured on callus induction medium II containing 0 (N0), $1 \mathrm{mg} / \mathrm{L}$ NAA (N1) and $2 \mathrm{mg} / \mathrm{L}$ NAA (N2), respectively. Data represent means \pm SE. Different letters indicate significant differences according to LSD test $(\mathrm{P}<$ $0.05)$.

\begin{tabular}{cccc}
\hline \multirow{2}{*}{ Genotype } & \multicolumn{3}{c}{ Callus induction rate (\%) on different induction } \\
medium II & N1 \\
\cline { 2 - 4 } & $\mathrm{N} 0$ & $\mathrm{~N} 2$ \\
\hline JN177 & $43.7 \pm 4.5 \mathrm{c}$ & $81.0 \pm 3.6 \mathrm{a}$ & $31.3 \pm 4.9 \mathrm{~d}$ \\
CS & $49.3 \pm 2.1 \mathrm{c}$ & $73.7 \pm 3.2 \mathrm{~b}$ & $26.3 \pm 4.0 \mathrm{~d}$ \\
\hline
\end{tabular}

Table 2. Callus induction rate of leaf basal segments from different size of leaves of the first generation wheat plantlets. Data represent means $\pm \mathrm{SE}$. Different letters indicate significant differences according to LSD test $(\mathrm{P}<0.05)$.

\begin{tabular}{cccc}
\hline \multirow{2}{*}{ Genotype } & \multicolumn{3}{c}{$\begin{array}{c}\text { Callus induction rate (\%) of leaf basal segments } \\
\text { from different leave size }\end{array}$} \\
\cline { 2 - 4 } & $2 \pm 0.5 \mathrm{~cm}$ & $4 \pm 0.5 \mathrm{~cm}$ & $6 \pm 0.5 \mathrm{~cm}$ \\
\hline \multirow{2}{*}{$\mathrm{NN} 177$} & $60.5 \pm 6.9 \mathrm{~b}$ & $87.2 \pm 4.2 \mathrm{a}$ & $43.9 \pm 4.1 \mathrm{c}$ \\
$\mathrm{CS}$ & $60.0 \pm 5.5 \mathrm{~b}$ & $79.4 \pm 5.8 \mathrm{a}$ & $40.5 \pm 6.0 \mathrm{c}$ \\
\hline
\end{tabular}

Table 3. Regeneration rate of the second generation wheat plantlets on differentiation medium II containing different amounts of $\mathrm{AgNO}_{3}$ or TIBA. R1: without $\mathrm{AgNO}_{3}$ or TIBA; R2: with only $10 \mathrm{mg} / \mathrm{L}_{\mathrm{AgNO}_{3}}$; R3: with only $1 \mathrm{mg} / \mathrm{L} \mathrm{TIBA}$; R4: with $10 \mathrm{mg} / \mathrm{L} \mathrm{AgNO}_{3}$ and $1 \mathrm{mg} / \mathrm{L} \mathrm{TIBA}$. Data represent means \pm SE. Different letters indicate significant differences according to LSD test $(\mathrm{P}<0.05)$.

\begin{tabular}{ccccc}
\hline \multirow{2}{*}{ Genotype } & \multicolumn{4}{c}{$\begin{array}{c}\text { Regeneration rate (\%) of second generation wheat } \\
\text { plantlets on different differentiation medium II }\end{array}$} \\
\cline { 2 - 5 } & $\mathrm{R} 1$ & $\mathrm{R} 2$ & $\mathrm{R} 3$ & $\mathrm{R} 4$ \\
\hline $\mathrm{JN} 177$ & $5.8 \pm 2.9 \mathrm{c}$ & $19.2 \pm 3.8 \mathrm{~b}$ & $20.8 \pm 2.7 \mathrm{~b}$ & $33.7 \pm 3.6 \mathrm{a}$ \\
$\mathrm{CS}$ & $5.0 \pm 2.5 \mathrm{c}$ & $21.7 \pm 3.5 \mathrm{~b}$ & $20.6 \pm 5.8 \mathrm{~b}$ & $27.7 \pm 4.3 \mathrm{ab}$ \\
\hline
\end{tabular}

cences were first induced and subcultured on callus induction medium I and callus subculture medium, respecttively. Embryogenic calli were then cultured on differentiation medium I to generate the first generation plantlets (Figure 1(a)). The $2 \mathrm{~mm}$ leaf basal segments of first generation plantlets were cut (Figure 1(b)) and cultured on callus induction medium II containing $1 \mathrm{mg} / \mathrm{L}$ NAA (Figure 1(c)). After 3 - 4 weeks of incubation, calli were observed from leaf basal segments at the anatomical basal side (Figures 1(d) and (e)). After the obtained calli were transferred onto differentiation medium II containing $10 \mathrm{mg} / \mathrm{L} \mathrm{AgNO}_{3}$ and $1 \mathrm{mg} / \mathrm{L}$ TIBA for 3 - 4 weeks, the second generation plantlets was regenerated (Figure 1(f)). The regenerated plants can grow well in soil and 


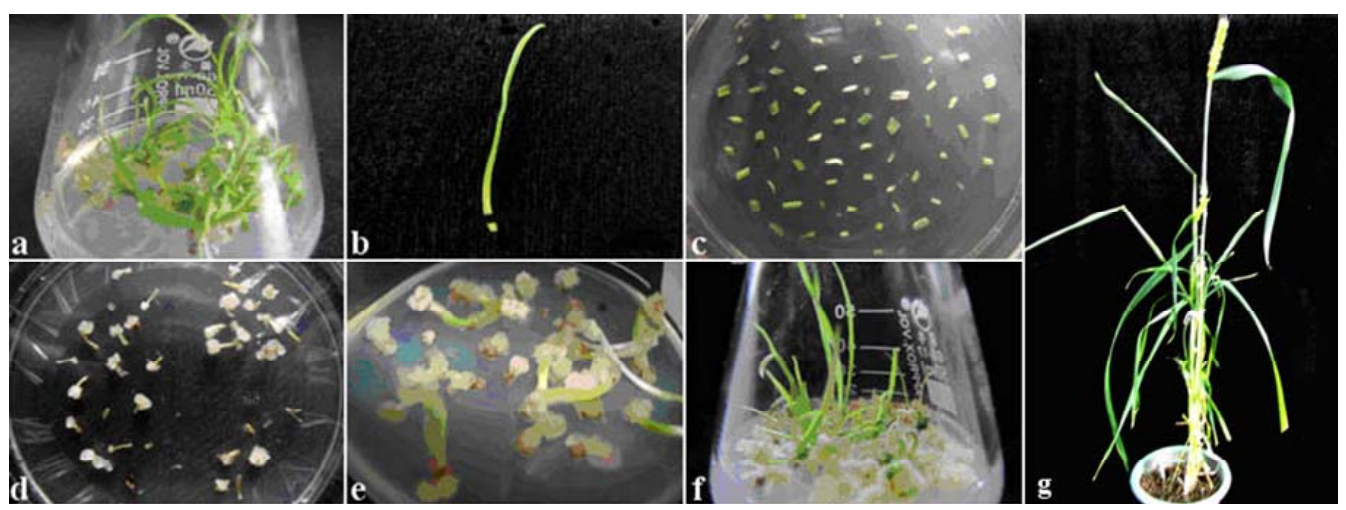

Figure 1. Representative regeneration process of the second generation wheat plantlets from the first generation wheat plants of JN177. (a) The first generation wheat plantlets were regenerated from calli of immature embryos; (b) The $2 \mathrm{~mm}$ leaf basal segment was cut from leaf of the first generation wheat plantlets; (c) The leaf basal segments were cultured on callus induction medium II; (d) and (e) Calli emerged from leaf basal segments; (f) The regeneration of the second generation wheat plantlets; (g) The regenerated plants were fertile.

set seeds (Figure 1(g)). Thus, our experiments established a high frequency wheat regeneration from leaf explants of regenerated plantlets.

\section{DISCUSSION}

Immature embryos or inflorescences of cereal crops are usually used as the starting material in their tissue culture and transgenic research. Although there have been several studies on plant regeneration from leaf basal segments of wheat seedlings $[1,2,8]$, the "leaf basal segment" used in these studies may have included a mixture of leaf tissue, coleoptile tissue, and possibly the apical meristem of 3 - 5-d-old wheat seedlings. In contrast to the reports mentioned above, we used only the leaf tissues from in vitro regenerated plantlets, not seedlings, as the explants to establish a repeated regeneration system of wheat plantlets.

The embryogenic potential of the wheat leaf basal tissues was determined by leaf size and the position of the leaf segments. Some authors have proposed that there are gradient changes in the cell cycle according to cell position from the leaf base to its apex $[9,10]$, and most cells in the basal region of seedlings have been shown to be at the $\mathrm{G}_{2}$ stage of the cell cycle. A decrease in the proliferative activity of cells in the apical region of a seedling was accompanied by a decrease in the number of cells at the $\mathrm{G}_{2}$ stage. Previous work has suggested that, in the leaf cells, the cell cycle stage and mitotic activity can determine the proliferative capacity of cells $[9,10]$. Therefore, it might be the case that the leaf basal segments of in vitro plantlet leaves with size $4 \pm 0.5 \mathrm{~cm}$ had the most cells in $\mathrm{G}_{2}$ stage, resulting in the highest embryogenic capacity and callus induction rate.

The present study demonstrated that $\mathrm{AgNO}_{3}$ and TIBA improved the regeneration rate of wheat (JN177 and CS) from leaf basal segments of the first generation plantlets. This result was consistent with the observation of Chugh and Khurana [1], suggesting that leaf basal segments from seedlings and in vitro regenerated plantlets gave similar responses to tissue culture conditions. $\mathrm{AgNO}_{3}$ is capable of enhancing somatic embryogenesis in cereals by inhibiting ethylene action and promoting shoot formation [11]. Auxins, such as 2,4-D in callus induction medium II, play a key role in somatic embryo induction, while their continuous presence may retard further progression of embryo differentiation and development [12, 13]. As an inhibitor of auxin polar transport, TIBA is known to have a negative influence on the developmenttal and structural aspects of somatic embryo maturation $[14,15]$. The fact that exogenously applied $\mathrm{AgNO}_{3}$ and TIBA enhanced the regeneration rate of the second generation plantlets could possibly be due to the inhibition of auxin transport in the presence of TIBA, which in combination with $\mathrm{AgNO}_{3}$ and kinetin enhanced the shoot formation of embryogenic calli [1].

\section{ACKNOWLEDGEMENTS}

We thank Dr. Zhongyi Li (CSIRO Division of Plant Industry, Canberra, Australia) for his reading and critical comments on the manuscript. We also thank Dr. Bo Wang for her assistance with the statistical analysis. This research was supported by the National High-Tech Research and Development Program of China (Grant No. 2007AA100505) and the Natural Science Foundation of Shandong Province (Grant No. Z2006D01) to B. H. and the Scientific Research Fund of Shandong Provincial Education Department (Grant No. J07WG03) to H. Y.

\section{REFERENCES}

[1] Chugh, A. and Khurana, P. (2003) Regeneration via somatic embryogenesis from leaf basal segments and ge- 
netic transformation of bread and emmer wheat by particle bombardment. Plant Cell, Tissue and Organ Culture, 74, 151-161. doi:10.1023/A:1023945610740

[2] Kopertekh, L.G. and Stribnaya, L.A. (2003) Plant regeneration from wheat leaf explants. Russian Journal of Plant Physiology, 50, 365-368. doi:10.1023/A:1023826304989

[3] Lee, S.M., Kang, K., Chung, H., Yoo, S.H., Xu, X.M., Lee, S.B., Cheong, J.J., Daniell, H. and Kim, M. (2006) Plastid transformation in the monocotyledonous cereal crop, rice (Oryza sativa) and transmission of transgenes to their progeny. Molecules and Cells, 21, 401-410.

[4] Murashige, T. and Skoog, F.A. (1962) A revised medium for rapid growth and bioassays with tobacco tissue culture. Physiologia Plantarum, 15, 473-497. doi:10.1111/j.1399-3054.1962.tb08052.x

[5] Gamborg, O.L., Miller, R.A. and Ojima, K. (1968) Nutrient requirement of suspension cultures of soybean root cells. Experimental Cell Research, 50, 151-158. doi:10.1016/0014-4827(68)90403-5

[6] Xia, G.M., Li, Z.Y., He, C.X., Chen, H.M. and Richard, B. (1999) Transgenic plant regeneration from wheat mediated by Agrobacterium tumefaciens. Acta Phytophysiologica Sinica, 25, 22-28.

[7] Yu, H.M., Xia, G.M. and Hou, B.K. (2005) Factors improving the efficiency of wheat transformation mediated by Agrobacterium tumefaciens. Journal of Shandong University, 40, 120-124.

[8] Chen, H.M., Teng, S.Y. and Yu, J.J. (1980) Callus induction and organ formation from young leaf of wheat. Botanica Sinica, 22, 112.
[9] Dolezelova, M., Dolezel, J. and Nesticky, M. (1992) Relationship of embryogenic competence in maize (Zea mays L.) leaves to mitotic activity, cell cycle and nuclear DNA content. Plant Cell, Tissue and Organ Culture, $\mathbf{3 1}$ 215-221.

[10] Chen, Z., Zhuge, Q. and Sundqvist, C. (1995) Oat leaf base: tissue with an efficient regeneration capacity. Plant Cell Report, 14, 354-358. doi:10.1007/BF00238596

[11] Fei, S., Read, P.E. and Riordan, T.P. (2000) Improvement of embryogenic callus induction and shoot regeneration of buffalograss by silver nitrate. Plant Cell, Tissue and Organ Culture, 60, 197-200. doi:10.1023/A:1006468324616

[12] Raghavan, V. (1997) Molecular embryology of flowering plants. Cambridge University Press, New York. doi:10.1017/CBO9780511574528

[13] Mahalakshmi, A., Khurana, J.P. and Khurana, P. (2003) Rapid induction of somatic embryogenesis by 2,4-D in leaf base cultures of wheat (Triticum aestivum L.). Plant Biotechnology, 20, 267-273. doi:10.5511/plantbiotechnology.20.267

[14] Liu, C.M., Xu, Z.H. and Chua, N.H. (1993) Auxin polar transport is essential for the establishment of bilateral symmetry during early plant embryogenesis. Plant Cell, 5, 621-630.

[15] Choi, Y.E, Kim, H.S., Soh, W.Y. and Yang, D.C. (1997) Developmental and structural aspects of somatic embryos formed on medium containing 2,3,5-triiodobenzoic acid. Plant Cell Report, 16, 738-744. doi:10.1007/s002990050312

\section{Abbreviations}

2,4-D: 2,4-dichlorophenoxyacetic acid;

6-BA: $N^{6}$-benzyladenine;

IAA: indole-3-acetic acid;

MS: Murashige and Skoog;

NAA: naphthalenacetic acid;

TIBA: 2,3,5-triiodobenzoic acid. 